Elsevier required licence: (C) <2018>. This manuscript version is made available under the CC-BY-NC-ND 4.0 license http://creativecommons.org/licenses/by-nc-nd/4.0/ 
Review

\title{
Assimilable organic carbon (AOC) variation in reclaimed water: Insight on biological stability evaluation and control for sustainable water reuse
}

\author{
Zhuo Chen ${ }^{\mathrm{a}, \mathrm{b}, 1}$, Tong $\mathrm{Yu}^{\mathrm{a}, 1}$, Huu Hao $\mathrm{Ngo}^{\mathrm{c}}$, Yun $\mathrm{Lu}^{\mathrm{a}}$, Guoqiang $\mathrm{Li}^{\mathrm{a}}$, Qianyuan $\mathrm{Wu}^{\mathrm{b}, \mathrm{d}}$, Kuixiao Li \\ Yu Bai ${ }^{e}$, Shuming Liu ${ }^{a}$, Hong-Ying $\mathrm{Hu}^{\mathrm{a}, \mathrm{d}, *}$ \\ ${ }^{a}$ Environmental Simulation and Pollution Control State Key Joint Laboratory, State Environmental Protection Key Laboratory of Microorganism Application and Risk \\ Control (SMARC), School of Environment, Tsinghua University, Beijing 100084, PR China \\ ${ }^{\mathrm{b}}$ Key Laboratory of Microorganism Application and Risk Control of Shenzhen, Graduate School at Shenzhen, Tsinghua University, Shenzhen 518055, PR China \\ ' School of Civil and Environmental Engineering, University of Technology Sydney, Broadway, NSW 2007, Australia \\ d Shenzhen Environmental Science and New Energy Technology Engineering Laboratory, Tsinghua-Berkeley Shenzhen Institute, Shenzhen 518055, PR China \\ ${ }^{\mathrm{e}}$ Research and Development Center, Beijing Drainage Group Co., Ltd, Beijing 100124, PR China
}

\section{G R A P H I C A L A B S R A C T}

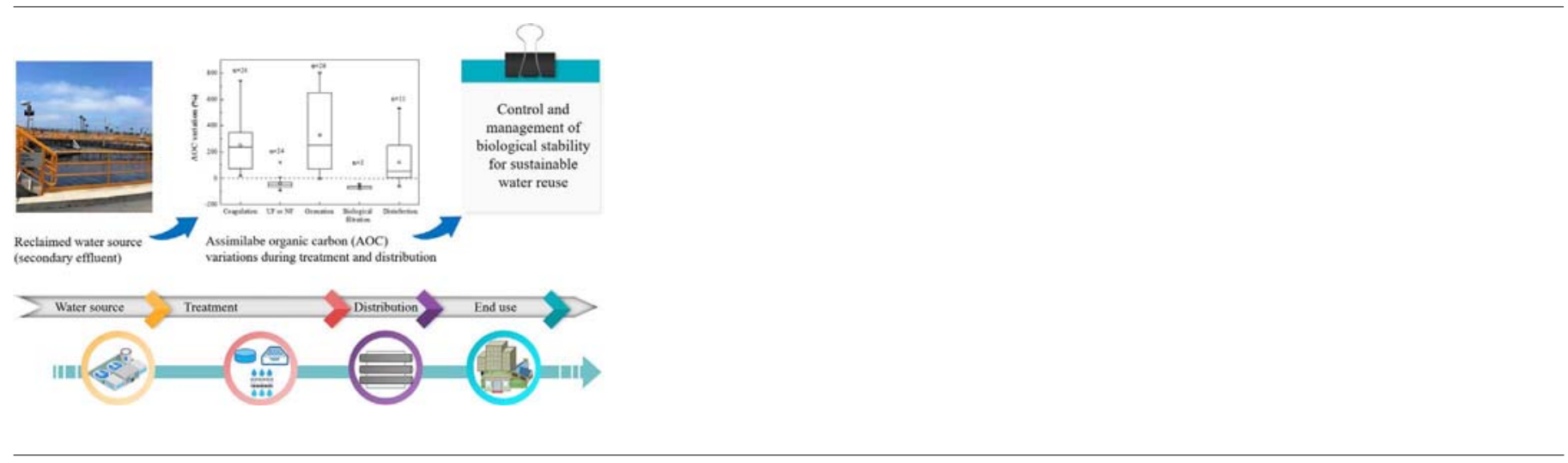

\section{A R T I C L E INFO}

\section{Keywords:}

Assimilable organic carbon (AOC)

Biological stability

Microbial regrowth

Reclaimed water

Sustainable water reuse

\begin{abstract}
A B S T R A C T
This review highlights the importance of conducting biological stability evaluation due to water reuse progression. Specifically, assimilable organic carbon (AOC) has been identified as a practical indicator for microbial occurrence and regrowth which ultimately influence biological stability. Newly modified AOC bioassays aimed for reclaimed water are introduced. Since elevated AOC levels are often detected after tertiary treatment, the review emphasizes that actions can be taken to either limit AOC levels prior to disinfection or conduct posttreatment (e.g. biological filtration) as a supplement to chemical oxidation based approaches (e.g. ozonation and chlorine disinfection). During subsequent distribution and storage, microbial community and possible microbial regrowth caused by complex interactions are discussed. It is suggested that microbial surveillance, AOC threshold values, real-time field applications and surrogate parameters could provide additional information. This review can be used to formulate regulatory plans and strategies, and to aid in deriving relevant control, management and operational guidance.
\end{abstract}

\footnotetext{
"Corresponding author at: EnvironmentalSimulationand Pollution ControlState Key Joint Laboratory, State Environmental Protection Key Laboratory of Microorganism Application and Risk Control (SMARC), School of Environment, Tsinghua University, Beijing 100084, PR China.

E-mail address: hyhu@tsinghua.edu.cn (H.-Y.Hu).

${ }^{1}$ These authors contributed equally to this article and are joint first authors.
} 


\section{Introduction}

Nowadays, water reuse is being increasingly considered as an important aspect to alleviate water-related challenges such as water scarcity and water environment contamination (Verstraete et al., 2009). With the continuous exploitation and development of water reuse applications, it is vital to guarantee the reclaimed water stability for longterm sustainable water reuse (Luo et al., 2014; Tran et al., 2015). Many studies have observed apparent microbial regrowth situations during water reuse practices, including open storage tanks (Ajibode et al., 2013), distribution systems (Jjemba et al., 2010; Thayanukul et al., 2013), and end uses, such as urban replenishment ponds, agricultural irrigation and industrial cooling systems (Alley, 2007). Excessive microbial regrowth in reclaimed water can cause nuisances, such as deterioration of odor and color, biofouling of membranes, clogging of facilities and corrosion of distribution pipes (Shan et al., 2005; Ghunmi et al., 2010). More importantly, the presence of some opportunistic pathogens can bring about health risks and public misgivings (Narasimhan et al., 2005). This could hinder the further expansion of water reuse market to a large extent. For instance, Legionella reportedly can survive in cooling water and ornamental water features using reclaimed water, which is likely to cause pneumonia symptoms or other health related diseases (Fykse et al., 2016).

Therefore, biological stability is one of the key issues to be evaluated in water reuse management in order to prevent microbial regrowth and reclaimed water quality deterioration (Ryu et al., 2005; Thayanukul et al., 2013). It is defined as the concept of maintaining microbial water quality from production up to consumption (ISO, 2017). It is further explained as the inability of water or a material in contact with water to support microbial growth in the absence of a disinfectant (van der Wielen and van der Kooij, 2010). Achieving and maintaining biological stability not only implies producing biologically stable water after treatment but also ensures that storage, distribution and end use processes not to generate or promote uncontrollable changes in microbial concentrations (Prest et al., 2016). Given the possibility of opportunistic pathogen regrowth in reclaimed water, microbial community and bioavailability of organic carbon can also be taken into account (Cheng et al., 2016).

To date, there is no unified method to quantify the biological stability of reclaimed water (Garner et al., 2016). It is generally noticed that concentrations of available organic and inorganic nutrients are major factors governing the extent of bacterial growth (Shan et al., 2005; Thayanukul et al., 2013, 2016). Organic carbon is considered as the dominant growth limiting compound for bacteria and biological stability is thusly often evaluated by biodegradable dissolved organic carbon (BDOC) and/or assimilable organic carbon (AOC) concentrations (Escobar et al., 2001; Prest et al., 2016). Moreover, some studies claimed that additional information on microbial community using advanced techniques, such as flow cytometry, adenosine triphosphate (ATP) and pyrosequencing can be complementary to conventional parameters to account for bacterial dynamics in storage and distribution (Lautenschlager et al., 2013; Prest et al., 2014). Nevertheless, AOC can be considered as the first evaluation of biological stability that can provide indications for optimization and control of treatment processes. Since AOC can still influence biological stability at $\mu \mathrm{g} / \mathrm{L}$ levels, there is a significant need to analyze the impacts of different treatment technologies on this indicator.

Consequently, this study aims to give an overview of existing biological stability indicators and add emphasis on AOC for assessment. Given distinct differences between reclaimed water and drinking water, a necessity to adopt the AOC bioassay that is specially targeted for reclaimed water is highlighted. Afterwards, the study evaluates how this indicator is influenced by different advanced water reuse treatment processes comprehensively, followed by a deep discussion on challenges and potential needs for biological stability control and management. Better insight into biological stability control of reclaimed water can produce more reliable risk assessment and help to guarantee sustainable water reuse.

\section{AOC for biological stability evaluation of reclaimed water}

\subsection{Typical approaches for biological stability evaluation}

A number of methods were reportedly used for biological stability evaluation. One approach is to quantify indigenous bacterial biomass (colony-forming units, CFU), such as bacterial growth potential (BGP) and biofilm formation rate (BFR) (Sathasivan and Ohgaki, 1999). Another alternative approach is to quantify changes of nutrients present in water, such as AOC, BDOC and microbially available phosphorus (MAP) (Wang et al., 2014a, b; Zhang et al., 2016). The comparisons and characteristics of different methods are listed in Table 1. Notably, AOC displays a better correlation with bacterial growth compared to BDOC (Escobar et al., 2001). It is defined as the fraction of labile dissolved organic carbon (DOC), namely the low molecular weight organic carbon contents, e.g. sugars, carboxylic acids and amino acids, that is more easily utilized and converted to cell mass by heterotrophic bacteria than the other types of organic carbon (Liu et al., 2015). Thus, AOC bioassay is widely adopted to give an indication of bacterial regrowth potential (Escobar et al., 2001; Zhao et al., 2013). However, since AOC measurements could not directly reflect microbial composition, not to mention the biological instability caused by autotrophic bacteria growth (e.g. denitrifying and ammonium oxidizing bacteria), some recent studies also call for the identification of microbial community changes in distribution systems (Lautenschlager et al., 2013; Prest et al., 2014).

\subsection{Measurement of AOC for biological stability evaluation}

\subsubsection{Typical AOC levels of drinking water and reclaimed water}

Dissolved organic matter (DOM) present in reclaimed water can be apparently distinct from that of drinking water in terms of DOC, dissolved organic nitrogen (DON) and AOC (Hu et al., 2016). Reclaimed water, even tertiary treated, usually contains higher amount of DOM in regard to soluble microbial products, synthetic organic compounds, etc. with greater fluctuations (Ma et al., 2013; Diamantis et al., 2014; Farooq et al., 2015; Verstraete et al., 2016; Bustamante and Liao, 2017). Specifically, AOC concentrations in most treated drinking water (after coagulation and/or ozonation processes) are less than $500 \mu \mathrm{g} / \mathrm{L}$, and over $80 \%$ of drinking water samples have AOC levels below $200 \mu \mathrm{g} / \mathrm{L}$ (Fig. 1). Afterwards, AOC levels are slightly decreased due to bacterial growth in pipelines (Liu et al., 2002).

Comparatively, AOC levels in reclaimed water could be 5-10 times higher than that of drinking water. Weinrich et al. (2010) conducted a survey of 21 water reclamation plants (WRP) in the U.S. and found an AOC level of reclaimed water from 45 to $3200 \mu \mathrm{g} / \mathrm{L}$ with a median value of $450 \mu \mathrm{g} / \mathrm{L}$. Besides, Thayanukul et al. (2013) investigated 6 WRPs in Japan and claimed that AOC levels of secondary effluent and tertiary effluent from various processes were $66-138 \mu \mathrm{g} / \mathrm{L}$ and $36-$ $446 \mu \mathrm{g} / \mathrm{L}$ (median: $316 \mu \mathrm{g} / \mathrm{L}$ ) respectively. In addition, based on 5 WRPs in China, Zhao et al. (2014a, 2014b) concluded that AOC levels of secondary effluent and tertiary effluent from various processes were 57-8150 $\mu \mathrm{g} / \mathrm{L}$ (median: $223 \mu \mathrm{g} / \mathrm{L}$ ) and 22-3036 $\mu \mathrm{g} / \mathrm{L}$ (median: $870 \mu \mathrm{g} /$ L) respectively. As can be seen from Fig. 1, AOC levels in tertiary effluent were much higher than that of secondary effluent. Significant variations of AOC levels existed due to the adoption of different treatment approaches. It is important to conduct further analyses since high AOC amount in reclaimed water has high potential to provide an environment for the rapid regrowth of certain microorganisms and affects biological stability (Thomure et al., 2014).

\subsubsection{AOC bioassay for reclaimed water}

The conventional AOC bioassay was developed originally in 
Table 1

Comparison of different methods for biological stability evaluation

\begin{tabular}{|c|c|c|c|c|c|c|c|}
\hline Method & Main concept & Measurement & $\begin{array}{l}\text { Test parameter } \\
\text { (units) }\end{array}$ & Strengths & Weaknesses & Suitable application field & References \\
\hline $\mathrm{AOC}$ & $\begin{array}{l}\text { The consumption of DOC for bacterial } \\
\text { biomass growth }\end{array}$ & $\begin{array}{l}\text { The maximum growth of a test } \\
\text { pure organism(s) or } \\
\text { indigenous bacteria that is } \\
\text { correlated with the DOC }\end{array}$ & $\begin{array}{l}\mu \mathrm{g} \text { acetate } \\
\text { carbon } \\
\text { equivalent/L }\end{array}$ & $\begin{array}{l}\text { - Bacterial need for organic } \\
\text { carbon is much higher than } \\
\text { other nutrients } \\
\text { - The results allow for } \\
\text { comparisons among } \\
\text { different water samples }\end{array}$ & $\begin{array}{l}\text { - Merely reflects the easily assimilable } \\
\text { part in DOC } \\
\text { - Complexity and labor-intensive in } \\
\text { manipulation }\end{array}$ & $\begin{array}{l}\text { Evaluation of microbial } \\
\text { regrowth in various water } \\
\text { qualities }\end{array}$ & $\begin{array}{l}\text { Hammes and Egli } \\
\text { (2005), Zhang et al. } \\
\text { (2016) }\end{array}$ \\
\hline BDOC & $\begin{array}{l}\text { The consumption of DOC to catabolize } \\
\text { organic carbon to } \mathrm{CO}_{2} \text { and/or new } \\
\text { biomass }\end{array}$ & $\begin{array}{l}\text { The difference between initial } \\
\text { DOC and final DOC }\end{array}$ & $\mathrm{mg} / \mathrm{L}$ & $\begin{array}{l}\text { - Bacterial requirement for } \\
\text { organic carbon is much } \\
\text { higher than any other } \\
\text { nutrient } \\
\text { - Encompasses almost all of } \\
\text { biodegradable organics }\end{array}$ & $\begin{array}{l}\text { - Less sensitivity for analysis (i.e. } \\
\text { detection limits are at least an order } \\
\text { of magnitude greater than AOC and } \\
\text { BGP) } \\
\text { - No significant correlation to } \\
\text { bacterial growth }\end{array}$ & $\begin{array}{l}\text { Evaluation of the reduction in } \\
\text { chlorine demand or DBPs } \\
\text { formation potential through a } \\
\text { biological process }\end{array}$ & $\begin{array}{l}\text { Sathasivan and Ohgaki } \\
\text { (1999), Escobar and } \\
\text { Randall (2001), Zhang } \\
\text { et al. (2016) }\end{array}$ \\
\hline BFR & $\begin{array}{l}\text { The rate and extent of biofilm } \\
\text { formation as a function of time }\end{array}$ & $\begin{array}{l}\text { The flux of substrate through } \\
\text { column or monitor }\end{array}$ & $\operatorname{pg} \operatorname{ATP} / \mathrm{cm}^{2} \cdot \mathrm{d}$ & $\begin{array}{l}\text { A considerable biofilm } \\
\text { formation can be developed } \\
\text { despite of low AOC levels }\end{array}$ & $\begin{array}{l}\text { - Very low concentrations of readily } \\
\text { biodegradable compounds may } \\
\text { affect biofilm formation } \\
\text { Test duration needs weeks to months } \\
\text { - Complexity in manipulation }\end{array}$ & $\begin{array}{l}\text { Determination of the ability of } \\
\text { water to promote biomass } \\
\text { accumulation }\end{array}$ & van der Kooij (1999) \\
\hline BGP & $\begin{array}{l}\text { The maximum bacterial count that can } \\
\text { achieve owing to diverse compounds } \\
\text { available in water and complex } \\
\text { interactions among indigenous } \\
\text { bacterial population }\end{array}$ & $\begin{array}{l}\text { The maximum bacterial count } \\
\text { after inoculation of indigenous } \\
\text { bacteria and incubation }\end{array}$ & $\mathrm{CFU} / \mathrm{mL}$ & $\begin{array}{l}\text { - The nature of limiting } \\
\text { nutrient is identified } \\
\text { - Indigenous inoculum could } \\
\text { better represent the system }\end{array}$ & $\begin{array}{l}\text { - Lack for guideline values and } \\
\text { standardized methods } \\
\text { - Difficulties in comparison for } \\
\text { different water samples and the } \\
\text { same sample under different time } \\
\text { and space scales }\end{array}$ & $\begin{array}{l}\text { Direct evaluation of what really } \\
\text { happens in the water sample }\end{array}$ & $\begin{array}{l}\text { Sathasivan and Ohgaki } \\
\text { (1999), Zhang et al. } \\
\text { (2016) }\end{array}$ \\
\hline MAP & $\begin{array}{l}\text { The bacterial maximum growth from } \\
\text { inoculation until stationary phase with } \\
\text { phosphorus as the standard substrate }\end{array}$ & $\begin{array}{l}\text { The linear relationship } \\
\text { between MAP value and the } \\
\text { concentration of phosphorus }\end{array}$ & $\mu \mathrm{g} \mathrm{PO} 4-\mathrm{P} / \mathrm{L}$ & $\begin{array}{l}\text { - Phosphorus can be } \\
\text { measured and controlled } \\
\text { even at low concentrations } \\
\text { - All bacterial need } \\
\text { phosphorus as vital part } \\
\text { compared to BDOC }\end{array}$ & $\begin{array}{l}\text { The growth-determining factor in most } \\
\text { waters is usually carbon, owing to the C: } \\
\mathrm{N}: \mathrm{P} \text { molecular ratio of bacteria and } \\
\text { biomass (100:10:1) }\end{array}$ & $\begin{array}{l}\text { Regions where microbial } \\
\text { growth in water is restricted by } \\
\text { phosphorus content rather than } \\
\text { organic carbon }\end{array}$ & $\begin{array}{l}\text { Lehtola et al. (1999), } \\
\text { Wang et al., (2014a, } \\
\text { 2014b) }\end{array}$ \\
\hline
\end{tabular}

Abbreviations: AOC, assimilable organic carbon; ATP, adenosine triphosphate; BDOC, biodegradable dissolved organic carbon; BFR, biofilm formation rate; BGP, bacterial growth potential; CFU, colony-forming units; DBPs, disinfection byproducts; DOC, dissolved organic carbon; MAP, microbially available phosphorus. 


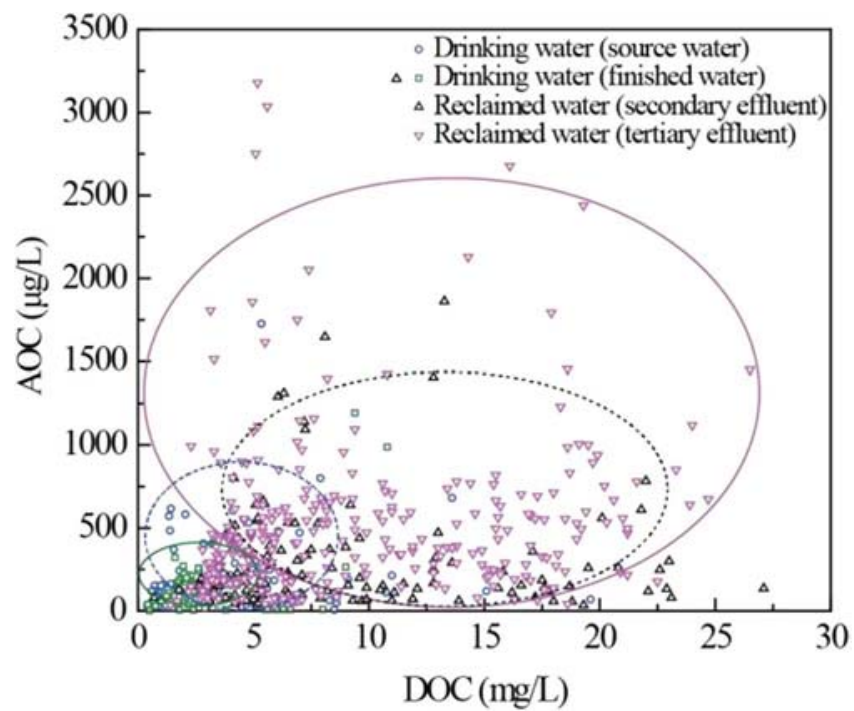

Fig. 1. AOC and DOC concentrations of reclaimed water and drinking water. Notes: statistical data were collected from scientific papers published in recent 15 years; the ovals in the chart indicate rough variation ranges of statistical data.

drinking water field where Pseudomonas fluorescens P17 and Spirillum sp. NOX were commonly taken as test strains (van der Kooij et al., 2015). Many studies have been performed to further modify, simplify and enhance the test speed. While some studies are devoted to optimizing inoculum and incubation conditions of plate count technique (Escobar et al., 2000), other AOC quantification approaches are also developed, such as turbidity method (Werner and Hambsch, 1986), ATP luminescence (LeChevallier et al., 1993), bioluminescence (Jeong et al., 2013), flow cytometry method (Hammes and Egli, 2005) and microbial fuel cell biosensor (Quek et al., 2014, 2015). Recently, an additional strain, Flavobacterium johnsoniae A3, is also considered in the AOC plate count test because of its ability to utilize proteins and polysaccharides that could not be utilized by strains P17 and NOX (van der Kooij et al., 2015). More detailed descriptions and comparisons on different AOC bioassays can be found in Ross et al. (2013) and Wang et al. (2014b). However, these methods are mostly established by experiments based on drinking water or seawater. Considering the distinct organic matter and microbial composition of reclaimed water compared to drinking water and seawater, information from existing AOC bioassays could be insufficient for biological stability evaluation of reclaimed water.

Consequently, Weinrich et al. (2009) developed bioluminescent strains which were mutagenized based on P17 and NOX with luxCDABE luminescence operon fusion and inducible transposons. They applied the modified bioluminescence test for AOC determination in reclaimed water and produced consistent results over a yearlong study. Still, the engineered strains were unable to fully reflect the complexity of reclaimed water. Besides, the difficulties in mutagenesis and low effectiveness of strains in low sensitivity luminometers also hinder its application. Furthermore, Zhao et al. (2013) discovered that AOC values of reclaimed water detected by three new strains, namely Stenotrophomonas sp. ZJ2, Pseudomonas saponiphila G3 and Enterobacter sp. G6 could be 2-8 times higher than that based on P17 and NOX. These newly adopted strains showed higher ability to utilize organic compounds in reclaimed water. They further declared that polymers and carbohydrates can be better utilized by ZJ2 and G3 whereas amines and carbohydrates can be better utilized by G6.

To address the diversity of natural microbial community in water samples, other recent studies were conducted by using indigenous microbial cultures as inoculum which is believed to better represent actual AOC levels in natural conditions. For example, Elhadidy et al. (2016) optimized the flow cytometry AOC method with an indigenous bacterial community. Over one year study, the method was found to be applicable to a wide range of water types including water bodies with high organic content. They further detected that microbial community with high nucleic acid content responded faster to an increase in nutrients or a decrease in water temperature. Although flow cytometry method is sensitive and can provide additional information of inactive and/or unculturable microorganisms, it tends to be costly and often has high levels of background for particles (Li et al., 2017).

Moreover, Li et al. (2017) optimized the procedures and conditions of ATP luminescence AOC bioassay method and used indigenous bacteria as inoculum for AOC determination in reclaimed water. This method is considered to be fast, stable and accurate for assessing and monitoring the AOC levels in reclaimed water. They reported that in reclaimed water, the indigenous microbial cultures could make better use of matrix carbons compared with the pure strains, but the complexity of microbial community could significantly influence the AOC. Nevertheless, this analysis may be subject to background interference (e.g. chemical compounds and free ATP in water).

Notably, the performance and suitability of different AOC bioassays largely depend on water quality characteristics. The uncertainties in some new strains and the complex interactions between different strains in indigenous microbial inoculum need further clarification (Wang et al., 2014b). Despite that the advanced AOC bioassays could significantly shorten the test time to 3-4 days and tend to provide a more accurate $A O C$ result than pure test strains, future studies are needed to overcome possible issues associated with microbial community impact and biological volume or ATP per cell (Li et al., 2017).

3. Effects of treatment and disinfection approaches on AOC levels for biological stability in water reuse systems

According to Fig. 2, in a typical water reuse system consisting of sequential treatment processes, distribution and intended use, AOC levels vary significantly and change seasonally. A high concentration of AOC introduces microbial growth potentials and leads to difficulties in reclaimed water quality management (Thayanukul et al., 2013; Yu et al., 2017). Thus, it is essential to further understand the effects of reclaimed water treatment processes on AOC levels and to identify the ideal treatment combination and/or management approach for biological stability control.

\subsection{Coagulation}

Coagulation normally promotes the interaction of small particles to form larger particles and is expected to reduce total dissolved solid levels and many other organic and inorganic constituents (Suarez et al., 2009; Thomure et al., 2014). In drinking water field, the effects of coagulation on AOC levels were reportedly inconsistent. Many articles observed a decrease of AOC concentrations ranging from 16 to $38 \%$ after coagulation and filtration (Liang and Ma, 2009; Zhang et al., 2016), and the removal of AOC measured by NOX ( $\mathrm{AOC}_{\text {NOx }}$ ) was generally less efficient than that measured by P17 (Wang et al., 2015). However, other studies reported little or no AOC removal by coagulation (Volk et al., 2000; Tian et al., 2008). They claimed that AOC was more difficult to be removed during coagulation than BDOC, probably because AOC was mainly composed of small, non-humic molecules that were not amenable to coagulation (Volk et al., 2000).

In terms of reclaimed water, Thayanukul et al. (2013) analyzed samples from 6 WRPs in Japan using P17 and NOX as test strains and stated that coagulation can lower the AOC amount in secondary effluents to some extent. Comparatively, Zhao et al. (2014a) adopted P17, NOX and three new strains, ZJ2, G3 and G6 for AOC test in China and noticed considerable increases in AOC levels in secondary effluents after coagulation. The study suggested that high molecular weight (>10 kDa) organic matters (e.g. polysaccharides and proteins) showed an inhibitory influence on microbial growth. The coagulation process mainly contributed to the removal of high molecular weight organic 


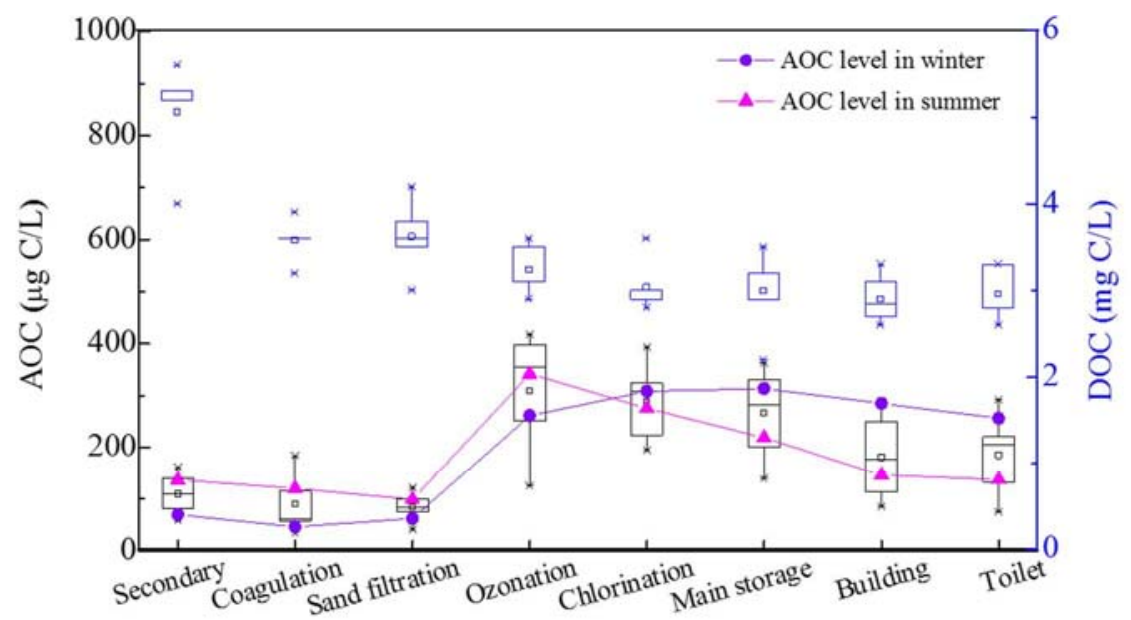

Fig. 2. AOC and DOC concentrations in reclaimed water along a typical water reuse system (data sourced from Thayanukul et al., 2013). Notes: In this dual Y-axis chart, the boxes and whiskers colored in black correspond to the $\mathrm{Y}$ axis on the left (i.e. AOC concentration). The boxes and whiskers colored in blue correspond to the $\mathrm{Y}$-axis on the right (i.e. DOC concentration)

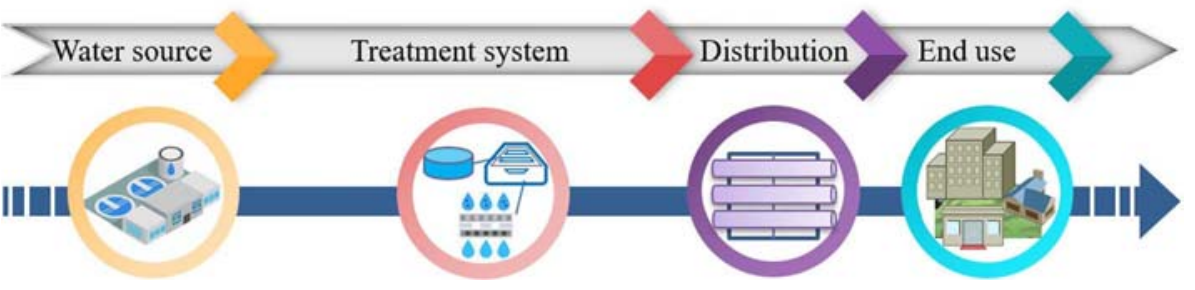

matters, resulting in AOC increase after coagulation. Similar results were obtained by Yu et al. (2017) in which membrane bioreactor (MBR) effluents after coagulation were analyzed. It was found that organic matters removed by coagulation that resulted in AOC increase were actually substances having aromaticity (indicated by ultraviolet absorbance at the $254 \mathrm{~nm}$ wavelength, $\mathrm{UV}_{254}$ ) but displaying little fluorescence. Overall, although coagulation process can remove DOM and DOC concentrations to some extent, this approach alone is unable to guarantee a biologically stable reclaimed water. Post-treatment processes need to be conducted in following steps.

\subsection{Membrane filtration}

Membrane filtration technologies mainly include microfiltration (MF), ultrafiltration (UF), nanofiltration (NF) and reverse osmosis (RO) (Guo et al., 2012). The pore size of MF and UF membranes are $0.1-1 \mu \mathrm{m}$ and 0.01-0.1 $\mu \mathrm{m}$ respectively (Yuan and He, 2015; Duncan et al., 2017; Zuthi et al., 2017). Since the organic matters less than $1 \mathrm{kDa}$ constitute the major part of AOC, MF and UF present little effect on AOC removal (LeChevallier, 1999). Moreover, some studies indicated that NF (pore size of $0.001-0.01 \mu \mathrm{m}$ ) could reduce AOC levels in drinking water to some extent but was not sufficient to restrict bacterial growth. The NF membranes could have an efficiency on AOC removal ranging from $34 \%$ to 95\% (Park et al., 2005; Meylan et al., 2007; Park et al., 2012). Nevertheless, other publications illustrated that NF could almost completely remove BDOC but did not influence AOC levels largely (LeChevallier, 1999; Escobar et al., 2001). Comparatively, RO showed clearly a better removal of AOC and could act as an efficient barrier (Liu et al., 2007; Meylan et al., 2007; Thayanukul et al., 2013). Noticeably, Escobar et al. (2000) suggested that apart from size exclusion, AOC removals by both NF and RO membranes were strongly affected by charge repulsion. The increased hardness and ionic strength or lower $\mathrm{pH}$ could lead to charge masking of negative surface charge of the membrane, thereby reducing the AOC removal significantly. Hence, water source quality also has a great impact on AOC removal.

In practice, membrane-based water reuse systems normally follow a sequence of filtration steps and dual membrane systems comprised of $\mathrm{MF} / \mathrm{UF}$ and RO modules are commonly applied. Pretreatment processes before $\mathrm{RO}$ can reduce the turbidity of feed water, mitigate membrane fouling potentials and enhance RO operation (Shan et al., 2005). Shan et al. (2005) demonstrated that a MF-RO system was able to achieve 96.1-98.7\% of AOC removal and the AOC was detected in the RO permeate ranged from 10 to $50 \mu \mathrm{g} / \mathrm{L}$. Furthermore, in full-scale WRPs with several treatment trains, $\mathrm{RO}$ could produce reclaimed water with significantly lower AOC content compared to other advanced treatment processes (Thayanukul et al., 2013).

\subsection{Ozonation}

Ozonation has been widely used for water and wastewater treatment and disinfection processes due to its strong oxidizability (Singh et al., 2008; Tripathi et al., 2011; Zhao et al., 2014b). However, sharp increases of AOC levels after ozonation have been discovered in both drinking water and reclaimed water treatment processes. For instance, in reclaimed water, several papers found that ozonation increased AOC by 3-7 times and a higher ozone dosage led to an elevated AOC production (Wert et al., 2007; Thayanukul et al., 2013; Zhao et al., 2014b).

The mechanism for the AOC increase during ozonation has been further studied. In drinking water field, some researches suggested that ozonation can transform larger molecules into smaller ones (e.g. aldehydes, ketones and organic acids), making the organic matters more biodegradable and easily be utilized by microorganisms (Hammes et al., 2006). In terms of reclaimed water, Zhao et al. (2014a) discovered that the decrease of high molecular weight (> $100 \mathrm{kDa}$ and $10-100 \mathrm{kDa})$ fractions by ozonation mainly caused AOC increase since they found that these fractions exhibited an inhibitory influence on microbial growth. The removal of large molecules before ozonation (e.g. via membrane filtration) could thus be considered so as to reduce the AOC formation potential during ozonation. In drinking water treatment, biological activated carbon (BAC) or biological filters are often equipped after ozonation for subsequent treatment of byproducts so as to ensure a good quality of the final effluent (Polanska et al., 2005; Wert et al., 2007). While in reclaimed water treatment systems, ozonation is

usually installed after sand filtration, membrane filtration and other biological treatment processes and is regarded as the last process before disinfection (Zhao et al., 2014b). In future system designs, it is indispensable to apply proper subsequent treatment to control AOC after ozonation. 


\subsection{Biological filtration and adsorption}

Biological filtration is considered to be a cost-effective and reliable technology for organic compound removal from water as well as waste gas streams (Yang et al., 2010; Iaconi, 2012). In drinking water treatment, biological filtration and adsorption process is usually equipped after ozonation for AOC control because ozonation process could transform larger molecules into smaller ones, resulting in an easier adsorption or a degradation of the byproducts through subsequent unit processes (Hu et al., 1999). For example, Yang et al. (2011) evaluated the AOC removal using ozone-BAC process and demonstrated that although ozonation increased the AOC level by $57 \%$, the following BAC process reduced the AOC level by $82 \%$ and achieved an average AOC level of $15 \mu \mathrm{g} / \mathrm{L}$. They suggested that both filtration by adsorption and biodegradation processes by beta-proteobacteria bacteria contributed to the AOC removal. Likewise, Hu et al. (1999) tested an ozone-granular activated carbon (GAC) system. They observed that AOC level was initially increased by $119 \%$ during ozonation but then decreased by $80 \%$ after GAC. Meanwhile, DOC level was also reduced by $11 \%$ afterGAC. The low AOC/DOC value indicated that GAC could enhance the biological stability of the effluent. At the same time, a biological ceramic treatment system was assessed, which was beneficial to minimize bacterial regrowth in distribution system by an AOC removal of about $45 \%$. In addition, Wert et al. (2008) operated an ozone-biofiltration system where the filtration system consisted of three filters equipping sand and anthracite filter media. They reported approximately $60 \%$ of AOC removal by biofiltration system.

However, it is worth noting that the effect of biological filtration processes on AOC removal may be subjected to seasonal changes. Ohkouchi et al. (2011) observed that although BAC could remove 50\% of AOC in summer, it could hardly reduce AOC level in winter season. At low water temperature, low bacterial activity to AOC could be the reason for low performance of BAC. Besides, along with operational time, fresh GAC is normally added to recover the adsorptive capacity, but it normally takes time to establish an effective biological activity as measured by reduction of AOC. Apart from possible long duration to achieve a stable performance, one major drawback of applying biological filtration is the detachment of biofilm and likely detection of bacteria (i.e. heterotrophic plate count, HPC or particle associated bacteria) in filtered water, which may lead to aesthetic issues such as high turbidity (Cecen and Aktas, 2011; NRC, 2012). Other factors that can affect biological filtration performance include mass transport, biofilter configuration, microbial competition and inhibition, etc. (Yang et al., 2010).

As for reclaimed water, current publications on ozone-BAC evaluation mainly focused on bulk water quality parameters (e.g. biochemical oxygen demand, BOD, chemical oxygen demand, COD, total organic carbon, TOC, ammonia nitrogen, $\mathrm{UV}_{254}$ absorbance and color) and trace organic contaminants (Wang et al., 2008; Gerrity et al., 2011; Iaconi, 2012), biological stability issues of combined systems were not assessed in detail. Since biological stability of reclaimed water can be significantly degraded after ozonation, biological treatment processes after ozonation might be considered for AOC control but further investigation is needed. In case of potentially low performance of biological filtration systems, some improvement in operation such as longer contact time can be needed to improve AOC removal (Ohkouchi et al., 2011; Matamoros et al., 2012).

\subsection{Disinfection}

Disinfection is normally considered as an important approach after the treatment train to limit bacterial occurrence where disinfectants such as ozone, chlorine, chloramine or ultraviolet (UV) irradiation are added (Silva et al., 2010). Several studies demonstrated that chlorine, chloramine and other oxidants for disinfection could increase the AOC levels in water (Okuda et al., 2006; Weinrich et al., 2010). Particularly,
Weinrich et al. (2010) investigated 4 WRPs in the U.S. and observed a large increase of $\mathrm{AOC}$ after chlorination and especially $\mathrm{AOC}_{\mathrm{NOx}}$ had been increased by an average of $290 \pm 61 \%$. NOX grew primarily on carboxylic acids and oxalate and higher concentration of $\mathrm{AOC}_{\mathrm{NO}}$ was related to oxidation byproducts from chlorine. As the oxidation potential of chloramine was less than that of chlorine, chloramine led to a lower degree of AOC increase. Moreover, Funamizu et al. (2004) evaluated the reaction of chlorine with organic matter in reclaimed water and implied that low molecular weight (less than $3000 \mathrm{Da}$ ) organic matter (i.e. AOC) gave the larger reaction rate. Comparatively, Ramseier et al. (2011) claimed that there was no significant AOC formation after applying chlorine dioxide and chlorine.

As for UV disinfection, conclusions regarding their effects on AOC concentrations from different publications are inconsistent. Some articles discovered increased AOC after UV irradiation and showed that the bioavailability of organic matter could be enhanced by UV as the generation of oxygen-rich compounds as well as the increase of low molecular weight compounds such as amino acids and carbohydrates (Shaw et al., 2000; Thayanukul et al., 2013). Higher UV irradiation doses could lead to elevated AOC concentrations (Ijpelaar et al., 2005). Nevertheless, others detected no obvious impact (Polanska et al., 2005) or even declined AOC levels (Lehtola et al., 2003). Differences in organic compositions, UV irradiation dosage and treatment performance might result in various effects (Thayanukul et al., 2013). Overall, the impact of UV disinfection on AOC was generally lower than that of chlorination and ozonation. Besides, for ozone disinfection, since ozonation could produce considerably high AOC levels (Section 3.3), this approach could hardly ensure the biological stability of reclaimed water in subsequent distribution and storage systems, which call for additional combined treatment and/or disinfection approaches.

\subsection{Comparison of different approaches on the impact of AOC levels}

As aforementioned, different treatment approaches exhibit distinct influences on AOC and DOC levels based on various mechanisms (Figs. 3 and 4). It can be concluded that for physical separation based approaches such as coagulation and membrane filtration, their effects

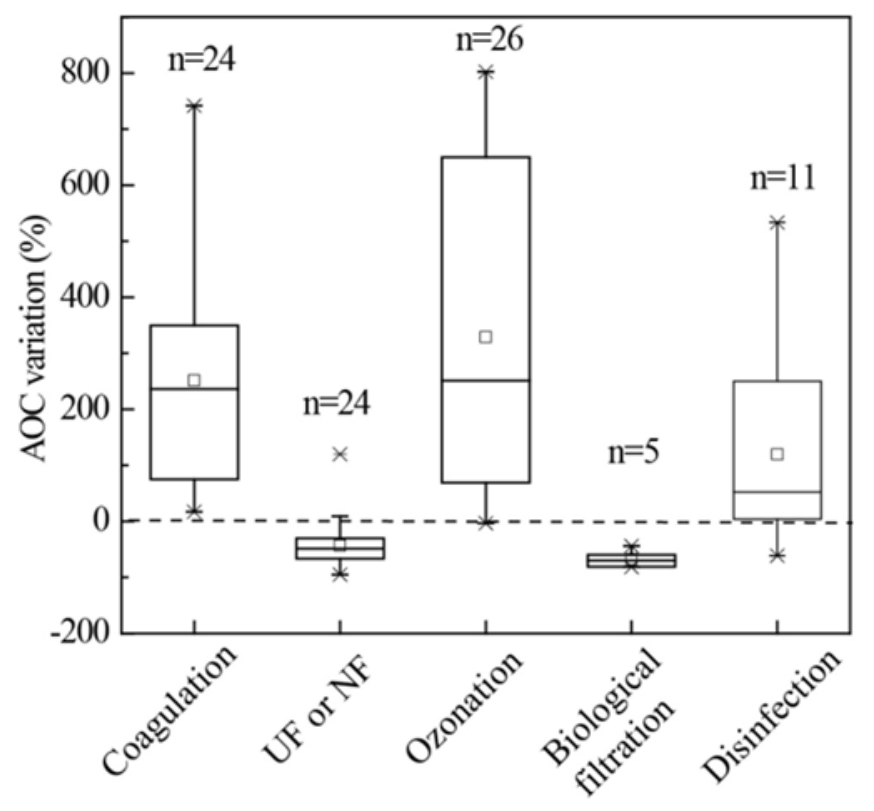

Fig. 3. AOC variations by different treatment approaches. Notes: $\mathrm{n}$ stands for the number of statistical data; (1) data of coagulation, ozonation and disinfection processes mainly sourced from Weinrich et al. (2010) and Zhao et al. (2014a, 2014b); (2) data of UF and NF processes sourced from LeChevallier (1999), Park et al. (2005) and Meylan et al. (2007); (3) data of biological filtration processes sourced from Hu et al. (1999), Wert et al. (2008) and Yang et al. (2011). 


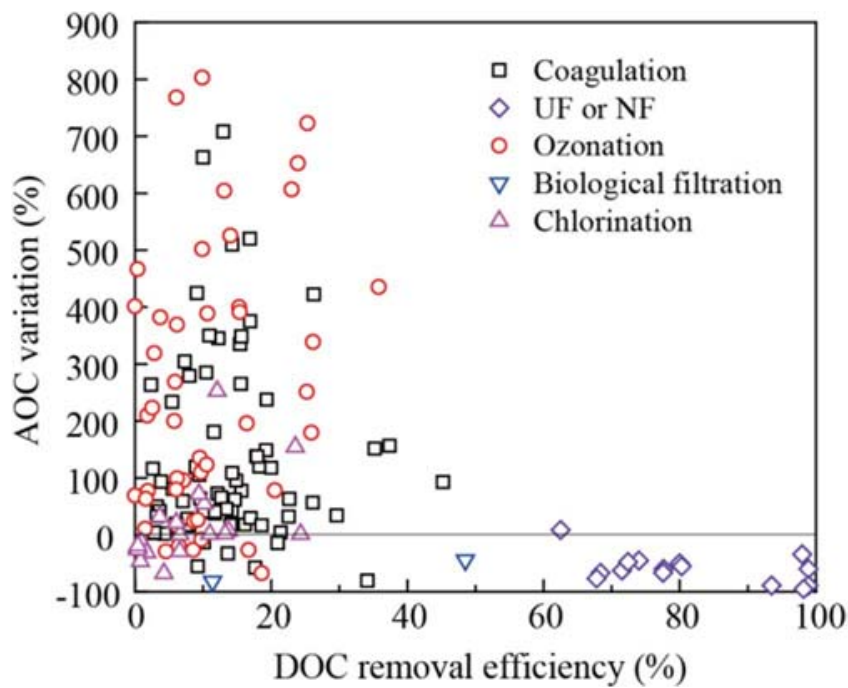

Fig. 4. AOC variations versus DOC removals by different treatment approaches. Notes: (1) data of coagulation, ozonation and chlorination processes mainly sourced from Zhao et al. (2014a, 2014b); (2) data of UF and NF processes sourced from LeChevallier (1999), Park et al. (2005) and Meylan et al. (2007); (3) data of biological filtration processes sourced from Hu et al. (1999).

on AOC and DOC removals are mainly based on size exclusion and charge repulsion. Particularly, high efficiency on DOC removal by coagulation and membrane filtration processes mainly results from the removal of large humic molecules and soluble microbial products (Zhao et al., 2014a). In comparison, chemical oxidation based approaches such as ozonation and disinfection produce apparently high levels of AOC due to oxidation effects. Nevertheless, the reported limited AOC removal (e.g. via coagulation, MF, UF and NF) or even significant AOC increase (e.g. via coagulation, ozonation and disinfection) suggest that the application of single treatment technology above could hardly result in a biologically stable reclaimed water. Hence, dual membrane systems comprised of MF/UF and RO modules are considered, where $\mathrm{RO}$ can produce a water with low AOC content. Alternatively, a final biologically active filter can be applied after ozonation or chlorine disinfection, which is capable of removing low molecular weight organic matters through biological oxidation degradation, filtration and adsorption. Noticeably, there are also possibilities that the abundant AOC precursors (i.e. hydrophilic organics such as poly- or oligosaccharides, peptides or proteins) will remain in finished water even after advanced treatment processes (e.g. BAC), which can contribute to a new AOC formation during water distribution and storage (Ohkouchi et al., 2011).

4. Control and management of biological stability for sustainable water reuse

Advanced treatment and disinfection call for the concerns on AOC levels. Moreover, as biochemical and microbial water quality may be changed considerably during water reuse distribution, storage and end uses, additional control and management of biological stability are also required for sustainable water reuse. In addition to $\mathrm{AOC}$, a number of factors may also contribute to biological instability, such as disinfectant residuals, temperature, $\mathrm{pH}$, hydraulic conditions, residence time, stagnation, pipe material and age of the distribution system, etc. (Ryu et al., 2005; Lautenschlager et al., 2013). Hence, the complex reactions among several variable factors are discussed, followed by practical control and management strategies.

\subsection{Disinfection and microbial surveillance in distribution and storage systems}

\subsubsection{Understanding relationship between AOC formation and several variables}

Generally, it is expected that high nutrient levels in conjunction with low disinfectant amount mainly initiate microbial proliferation in reclaimed water distribution systems (Lee et al., 2015). Disinfection helps to reduce microbial contamination by maintaining disinfectant residuals such as free chlorine and chloramine throughout the distribution system. Particularly, systems with high AOC concentrations are needed to maintain high disinfectant levels. Nevertheless, although super-chlorination or rechlorination can temporarily reduce microbial concentrations, due to rapid dissipation of chlorine in distribution systems, subsequent regrowth of microorganisms and indicators will still occur (Thayanukul et al., 2016). Disinfectant residuals also raise the concerns on disinfection byproducts (DBPs) formation, chlorinous odor and taste and biocorrosion of pipelines (Garner et al., 2016; Thayanukul et al., 2016). Besides, disinfectant residuals can react with particles, organics and pipe material releasing AOC that can be consumed by microorganisms, contributing to biological instability (Polanska et al., 2005; Ramseier et al., 2011).

Specifically, high levels of disinfectant residuals cannot always completely eliminate bacterial growth (Liu et al., 2002; Ryu et al., 2005). LeChevallier et al. (1996) showed that with the increment of disinfectant levels, the incidence of coliform bacteria detection initially decreased and then increased as a result of elevated AOC levels and greater formation of DBPs. Following such rapid regrowth, microbial concentrations in reclaimed water remained constant despite prolonged residence time along the length of pipes. This could be due to the fact that when the oxidation is completed, AOC concentrations become constant as some microorganisms continue to grow, while others are dead and are lysed (Ajibode et al., 2013). In terms of microbial community, Bautista-de los Santos et al. (2016) analyzed disinfected and disinfectant residual-free drinking water distribution systems by $16 \mathrm{~S}$ ribosomal ribonucleic acid gene sequencing method and claimed that the differences of microbial occurrence were largely attributed to selective pressures exerted by the process of disinfection. However, current research on the use of such techniques within the context of reclaimed water is still limited. As for temperature effect, low bacterial activity in winter may account for a lower AOC reduction in distribution system (Fig. 2).

Apart from distribution systems, storage tanks and open reservoirs also provide opportunities for AOC to increase as a result of algal growth from photosynthesis, re-disinfection and contamination. Noticeably, algal cells can be a considerable source of biodegradable carbon, especially when being exposed to an oxidant such as chlorine (LeChevallier, 1999; Jjemba et al., 2010). Hence, maintaining the quality of reclaimed water as it travels through distribution and storage systems can be challenging.

It is vital to understand the interactions between two effects, namely the disinfectant residual and the AOC level, in reclaimed water distribution and storage systems. The information can give indications for water utilities and/or operators on either disinfectant dosage or AOC control for bacterial regrowth control. In general, prior to optimization of disinfectant residual, enhancement of AOC removal can be necessary. Supplemental treatment at end use sites can also be conducted when needed. Some studies have established biological stability curves in drinking water distribution systems where acceptable AOC levels at different chlorine residual can be calculated out (Srinivasan and Harrington, 2007; Ohkouchi et al., 2012). Similar biological stability curves for water reuse systems can also be considered in future research.

4.1.2. Microbial surveillance and proposal of new indicators in guidelines A certain amount of AOC concentrations in reclaimed water 
primarily accounts for bacterial growth. Particularly, many studies have detected that water-based opportunistic pathogens (e.g. Aeromonas, Legionella, Mycobacterium and Pseudomonas) presented more frequently in reclaimed water distribution and storage systems than waterborne indicators (e.g. Escherichia coli, Enterococci and coliforms) (Norton et al., 2004; Ajibode et al., 2013). Jjemba et al. (2010) concluded that Mycobacterium was more often detected than other species, which occurred most frequently in MBR systems.

Opportunistic pathogens have several distinct characteristics which ease their proliferation in reclaimed water distribution and storage systems. They can be resistant to disinfection, reside in biofilms which act as shields from the bulk water environment, and are capable of growing at low organic carbon concentrations. The absence of competitive microflora and stagnation of water in systems are also conducive to their growth (Edwards et al., 2013; Garner et al., 2016). Although health risks related to these pathogens in reclaimed water (e.g. infectious doses and magnitude of exposure) are under-researched, it is worth noting that unlike most fecal pathogens, opportunistic pathogens infect via alternative routes (e.g. skin, eyes or lungs) rather than typically impacting the gastrointestinal system. An overview of non-traditional routes of exposure to opportunistic pathogens in reclaimed water can be found in Garner et al. (2016).

Thus, if reclaimed water is only supplied for applications with limited public exposure, fecal indicators might be adequate to be used for water quality monitoring at the WRP and within the distribution and storage system. However, for water reuse applications in which exposure routes may involve the inhalation of aerosols (e.g. cooling towers, toilet flushing, car washing and road cleaning) and/or dermal contact (e.g. landscape irrigation and recreational uses), special concerns should be given to opportunistic pathogens. Additional studies in health risk assessment should be further carried out to better understand the microbial quality and health risks of water-based pathogens (Jjemba et al., 2010, Thomure et al., 2014; Garner et al., 2016).

Currently, most of the existing guidelines for reclaimed water quality monitoring only focus on indicator bacteria, namely coliforms, E. coli and HPCs for reclaimed water quality monitoring (US EPA, 2012). However, these indicator organisms are mostly non-pathogenic and various studies have reported that the absence of indicator bacteria did not preclude the survival and regrowth of potentially pathogenic organisms (Jjemba et al., 2010). These findings suggested the need for microbial surveillance as well as the necessity of new indicators for water-based pathogens to be further researched and proposed (Ajibode et al., 2013; Thomure et al., 2014).

\subsection{Establishment of threshold values of AOC for biologically stable reclaimed water}

Having identified the importance of AOC control for restricting microbial growth and indicating regrowth potential in water reuse systems, biological stability curves can be developed based on HPC or coliform growth, AOC test and disinfectant residual data. According to these curves, threshold values of AOC can be identified under different scenarios, below which water can be considered as biologically stable (Shan et al., 2005). Proposed threshold values of AOC to achieve biological stability in drinking water can be found in Page and Dillon (2007), Ohkouchi et al. (2012) and Thayanukul et al. (2013).

Presently, there is no published threshold value of AOC for biological stability control and management of reclaimed water. Given the abundance of organic matter and unique nature of microbial composition in reclaimed water, the established AOC threshold values in drinking water cannot be transferred to reclaimed water simply and directly. As a consequence, the establishment of proper AOC threshold values in reclaimed water still needs more investigations. As such, it is suggested to consider the application of advanced AOC bioassay techniques and determine the allowable HPC growth according to different water reuse purposes and water quality requirements. It is also important to take into account of temperature, $\mathrm{pH}$, pipe material, biofilm formation and planktonic bacterial growth (Srinivasan and Harrington, 2007). The identified threshold values of AOC in reclaimed water could contribute to the feasibility and effectiveness of biological stability goals for sustainable water reuse.

\subsection{Rapid AOC assessment tool and possible surrogate for AOC formation}

Although AOC bioassay is a viable and effective research tool for assessing biological stability of reclaimed water, it could be difficult to be applied for real-time process control and management at WRPs, distribution system and end use sites owing to the prolonged measurement time, cost and technical expertise requirements. Under these circumstances, some fast analysis kits, techniques or modelling tools are increasingly being developed, such as the microbial fuel cell based AOC biosensor under marine conditions (Quek et al., 2015) and rapid bioluminescence AOC tests based on Vibrio fischeri (Jeong et al., 2013). These tools are able to dramatically reduce the bioassay time to several hours or even few minutes, but their stability in performance, procedures and possible field application for reclaimed water still require extensive investigation.

Alternatively, readily measurable surrogate parameters of AOCcan provide an approach to evaluate water quality characteristics without performing difficult and tedious analyses (Dickenson et al., 2009). As oxalate is a known product formed through oxidation of DOMs by most oxidants, Ramseier et al. (2011) evaluated the relationship between the oxalate formation and AOC during ozonation. Because of a weak correlation, they concluded that oxalate could not be considered as a surrogate for AOC formation during oxidative water treatment. Comparatively, other publications discovered that differentials in $U_{254}$ absorbance removal (i.e. organic matters with aromaticity) could serve as potentially viable surrogates to assess the formation of AOC during reclaimed water ozonation process (Dickenson et al., 2009). The reduction of $\mathrm{UV}_{254}$ absorbance could generally suggest the reaction of ozone with aromatic and humic contents in water (Weishaar et al., 2003) and ozonation could result in the changes of high molecular weight organic matters thereby leading to elevated AOC levels. Therefore, the real-time monitoring of $\mathrm{UV}_{254}$ absorbance fluctuations during reclaimed water ozonation process at WRPs is likely to provide indications for the variations of water quality biological stability and system failures. Additional possible surrogates for AOC can be further researched in future studies.

\section{Perspectives and future research directions}

While advanced treatment and disinfection technologies can generally produce high quality reclaimed water in terms of conventional indicators (e.g. BOD, COD, TOC and nutrient removal), their effects on significant AOC changes are often neglected. For efficient biological stability control, understanding the variation of AOC levels during treatment trains becomes important. Based on existing literature, biological treatment approaches in addition to chemical oxidation technologies (e.g. ozonation and chlorine disinfection) are suggested to be conducted and researched further to effectively remove AOC fractions. Alternatively, attentions could be paid to limit AOC concentrations in reclaimed water. A major knowledge gap is to what degree AOC level should be quantitatively controlled. Establishing biological stability curves and AOC threshold values may possibly help to fill this gap but requires further detailed research. A number of factors such as ambient environment, HPC growth, AOC level, disinfectant residual should be determined.

For biological safety concerns, further research is also needed for the interactions and competition processes between general bacteria and pathogens. The identification of opportunistic pathogens in reclaimed water distribution systems enlarges current cognition on the diversity and structure of dominant microbial communities in 
reclaimed water. This meanwhile call for microbial surveillance in water quality monitoring and new indicators to be developed in guidelines and/or regulations. In terms of analytical techniques, the diversity of microbial species and their competition processes for AOC highlight the importance of using direct microbial qualitative and quantitative tools. It is worth mentioning that although recent advanced molecular techniques are able to quantify the microbial quantity and type in reclaimed water, indicator parameters (e.g. AOC) are important to give an overall indication of bacterial regrowth potential. Future studies should expand AOC analyses from laboratory research into real-time field applications, particularly along with the reclaimed water distribution and storage systems.

\section{Conclusions}

With the growing trend of water reuse worldwide, issues on biological stability of reclaimed water raise concern. To produce a biologically stable water, restricting the AOC level during advanced treatment trains is indispensable, which can create a nutritionally stressed environment for microorganisms, while restricting reactions of organic compounds with disinfectants in the subsequent reclaimed water distribution, storage and end uses. Continuous understanding on microbial composition and surveillance can further help to perform sound control and management strategies. Development of rapid assessment tools and surrogates can extend the application of biological stability assessment into field practices.

\section{Acknowledgements}

This work was supported by the National Key R\&D Program of China (2016YFE0118800 \& 2017YFF0206702) and the National Science Foundation for Post-doctoral Scientists of China (2015M570114).

\section{References}

Ajibode, O.M. Rock, C., Bright, K., McLain, J.E.T., Gerba, C.P., Pepper, I.L., 2013. Influence of residence time of reclaimed water within distribution systems on water quality. J. Water Reuse Desal. 3, 185-196.

Alley, E.R., 2007. Water Quality Control Handbook, 2nd Edition. WEF Press

Bautista-de los Santos, Q.M., Schroeder, J.L., Sevillano-Rivera, M.C., Sungthong, R., Ljaz, U., Sloan, W.T., Pinto, A.J., Emerging investigators series: microbial communities in full-scale drinking water distribution systems - a meta-analysis. Environ. Sci. Water Res Technol. 22016631644.

Bustamante, M., Liao, W., 2017. A self-sustaining high-strength wastewater treatment system using solar-bio-hybrid power generation. Bioresour. Technol. 234, 415-423.

Cecen, F., Aktas, O., 2011. Activated Carbon for Water and Wastewater Treatment: Integration of Adsorption and Biological Treatment. WILEY-VCH, Singapore.

Cheng, Y., He, H., Yang, C., Zeng, G., Li, X., Chen, H., Yu, G., 2016. Challenges and solutions for biofiltration of hydrophobic volatile organic compounds. Biotechnol. Adv. 34, 1091-1102.

Diamantis, V., Eftaxias, A., Bundervoet, B., Verstraete, W., 2014. Performance of the biosorptive activated sludge (BAS) as pre-treatment to UF for decentralized wastewater reuse. Bioresour. Technol. 156, 314-321.

Dickenson, E.R.V., Drewes, J.E., Sedlak, D.L., Wert, E.C., Snyder, S.A., 2009. Applying surrogates and indicators to assess removal efficiency of trace organic chemicals during chemical oxidation of wastewaters. Environ. Sci. Technol. 43, 6242-6247.

Duncan, J., Bokhary, A., Fatehi, P., Kong, F., Lin, H., Liao, B., 2017. Thermophilic membrane bioreactors: a review. Bioresour. Technol. 243, 1180-1193.

Edwards, M., Pruden, A., Falkinham, J., Brazeau, R., Williams, K., Wang, H., Martin, A., Rhoads, W., 2013. Relationship between biodegradable organic matter and pathogen concentrations in premise plumbing. Water Research Foundation.

Elhadidy, A.M., Van Dyke, M.I., Peldszus, S., Huck, P.M., 2016. Application of flow cytometry to monitor assimilable organic carbon (AOC) and microbial community changes in water. J. Microbiol. Methods 130, 154-163.

Escobar, I.C., Hong, S., Randall, A.A., 2000. Removal of assimilable organic carbon and biodegradable dissolved organic carbon by reverse osmosis and nanofiltration membranes. J. Membr. Sci. 175 (1), 1-17.

Escobar, I., Randall, A., 2001. Assimilable organic carbon (AOC) and biodegradable dissolved organic carbon (BDOC): complementary measurements. Water Res. 35 (18), $4444-4454$.

Escobar, I., Randall, A., Taylor, J., 2001. Bacterial growth in distribution systems: effect of assimilable organic carbon (AOC) and biodegradable dissolved organic carbon (BDOC). Environ. Sci. Technol. 35, 3442-3447.

Farooq, W., Suh, W.I., Park, M.S., Yang, J.W., 2015. Water use and its recycling in microalgae cultivation for biofuel application. Bioresour. Technol. 184, 73-81.

Fykse, E.M., Aarskaug, T., Madslien, E.H., Dybwad, M., 2016. Microbial community structure in a full-scale anaerobic treatment plant during start-up and first year of operation revealed by high-throughput 16S rRNA gene amplicon sequencing. Bioresour. Technol. 222, 380-387.

Funamizu, N., Iwamoto, T., Takakuwa, T., 2004. Mathematical model for describing reactions of residual chlorine with organic matter in reclaimed wastewater. Water Sci. Technol. 50 (2), 195-201.

Garner, E., Zhu, N., Strom, L., Edwards, M., Pruden, A., 2016. A human exposome framework for guiding risk management and holistic assessment of recycled water quality. Environ. Sci. Water Res. Technol. 4, 580-598.

Gerrity, D., Gamage, S., Holady, J.C., Mawhinney, D.B., Quiñones, O., Trenholm, R.A., Snyder, S.A., 2011. Pilot-scale evaluation of ozone and biological activated carbon for trace organic contaminant mitigation and disinfection. Water Res. 45, 2155-2165.

Ghunmi, L.A., Zeeman, G., Fayyad, M., van Lier, J.B., 2010. Grey water treatment in a series anaerobic - aerobic system for irrigation. Bioresour. Technol. 101, 41-50.

Guo, W., Ngo, H.H., Li, J., 2012. A mini-review on membrane fouling. Bioresour. Technol. $122,27-34$.

Hammes, F.A., Egli, T., 2005. New method for assimilable organic carbon determination using flow-cytometric enumeration and a natural microbial consortium as inoculum. Environ. Sci. Technol. 39 (9), 3289-3294.

Hammes, F., Salhi, E., Koster, O., Kaiser, H.P., Egli, T., von Gunten, U., 2006. Mechanistic and kinetic evaluation of organic disinfection by-product and assimilable organic carbon (AOC) formation during the ozonation of drinking water. Water Res 40 (12), $2275-2286$.

Hu, J., Wang, Z., Ng, W., Ong, S., 1999. The effect of water treatment processes on the biological stability of potable water. Water Res. 33 (11), 2587-2592.

Hu, H.Y., Du, Y., Wu, Q.Y., Zhao, X., Tang, X., Chen, Z., 2016. Differences in dissolved organic matter between reclaimed water source and drinking water source. Sci. Total Environ. 551-552, 133-142.

Iaconi, C.D., 2012. Biological treatment and ozone oxidation: integration or coupling? Bioresour. Technol. 106, 63-68.

Ijpelaar, G.F., van der Veer, A.J., Medema, G.J., Kruithof, J.C., 2005. By-product formation during ultraviolet disinfection of a pretreated surface water. J. Environ. Eng. Sci. 4 (1), 51-56.

ISO 20670, 2017. Water reuse-Vocabulary. International Standard Organization.

Jeong, S., Naidu, G., Vigneswaran, S., Ma, C.H., Rice, S.A., 2013. A rapid bioluminescence-based test of assimilable organic carbon for seawater. Desalination 317, 160 165.

Jjemba, P.K., Weinrich, L.A., Cheng, W., Giraldo, E., LeChevallier, M.W., 2010. Regrowth of potential opportunistic pathogens and algae in reclaimed-water distribution systems. Appl. Environ. Microbiol. 76 (13), 4169-4178.

Lautenschlager, K., Hwang, C., Liu, W.T., Boon, N., Köster, O., Vrouwenvelder, H., Egli, T., Hammes, F., 2013. A microbiology-based multi-parametric approach towards assessing biological stability in drinking water distribution networks. Water Res. 47 3015-3025.

LeChevallier, M.W., Shaw, N.E., Kaplan, L.A., Bott, T.L., 1993. Development of a rapid assimilable organic carbon method for water. Appl. Environ. Microbiol. 59 (5), 1526 1531.

LeChevallier, M.W., Welch, N.J., Smith, D.B., 1996. Full-scale studies of factors related to coliform regrowth in drinking water. Appl. Environ. Microbiol. 62, 2201-2211.

LeChevallier, M.W., 1999. The case for maintaining a disinfectant residual. J. Am. Water Works Assoc. 91 (1), 86-94.

Lee, O., Kim, H.Y., Park, W., Kim, T., Yu, S., 2015. A comparative study of disinfection efficiency and regrowth control of microorganism in secondary wastewater effluent using UV, ozone, and ionizing irradiation process. J. Hazard. Mater. 295, 201-208.

Lehtola, M.J., Miettinen, I.T., Vartiainen, T., Martikainen, P.J., 1999. A new sensitive bioassay for determination of microbially available phosphorus in water. Appl. Environ. Microbiol. 65 (5), 2032-2034.

Lehtola, M.J., Miettinen, I.T., Vartiainen, T., Rantakokko, P., Hirvonen, A., Martikainen, P.J., 2003. Impact of UV disinfection on microbially available phosphorus, organic carbon, and microbial growth in drinking water. Water Res. 37 (5), 1064-1070.

Li, G.Q., Yu, T., Wu, Q.Y., Lu, Y., Hu, H.Y., 2017. Development of an ATP-based method for assimilable organic carbon determination in reclaimed water. Water Res. 123, 345352.

Liang, T., Ma, J., 2009. Variation of assimilable organic carbon during coagulation by aluminumand ironin drinking water treatment.J.WaterSupply Res. Technol. AQUA 58 (6), 416-423.

Liu, W., Wu, H., Wang, Z., Ong, S.L., Hu, Y.J., Ng, J.W., 2002. Investigation of assimilable organic carbon (AOC) and bacterial regrowth in drinking water distribution system. Water Res. 36, 891-898.

Liu, S., LePuil, M., Taylor, J., Randall, A., 2007. Nanofiltration and reverse osmosis biostability relative to alternative methods of water treatment. J. Water Supply Res Technol. AQUA 56 (1), 25-40.

Liu, X., Wang, J., Liu, T., Kong, W., He, X., Jin, Y., Zhang, B., 2015. Effects of assimilable organic carbon and free chlorine on bacterial growth in drinking water. PLOS One 10 (6), e0128825.

Luo, W., Hao, F.I., Price, W.E., Guo, W., Ngo, H.H., Yamamoto, K., Nghiem, L.D., 2014 High retention membrane bioreactors: challenges and opportunities. Bioresour. Technol. 167, 539-546.

Ma, D., Gao, B., Sun, S., Wang, Y., Yue, Q., Li, Q., 2013. Effects of dissolved organic matter size fractions on trihalomethanes formation in MBR effluents during chlorine disinfection. Bioresour. Technol. 136, 535-541.

Matamoros, V., Sala, L., Salvadó, V., 2012. Evaluation of a biologically-based filtration water reclamation plant for removing emerging contaminants: a pilot plant study. Bioresour. Technol. 104, 243-249. 
Meylan, S., Hammes, F., Traber, J., Salhi, E., von Gunten, U., Pronk, W., 2007. Permeability of low molecular weight organics through nanofiltration membranes. Water Res. 41 (17), 3968-3976.

Narasimhan, R., Brereton, J., Abbaszadegan, M., Ryu, H., Butterfield, P., Thompson, K., Werth, H., 2005. Characterizing Microbial Water Quality in Reclaimed Water Distribution Systems. AWWA Research Foundation.

Norton, C.D., LeChevallier, M.W., Falkinham III, J.O., 2004. Survival of Mycobacterium avium in a model distribution system. Water Res. 38, 1457-1466.

National Research Council (NRC), 2012. Water reuse: potential for expanding the nation's water supply through reuse of municipal wastewater. National Academy of Sciences.

Ohkouchi, Y., Ly, B.T., Ishikawa, S., Aoki, Y., Echigo, S., Itoh, S., 2011. A survey on levels and seasonal changes of assimilable organic carbon (AOC) and its precursors in drinking water. Environ. Technol. 32 (14), 1605-1613.

Ohkouchi, Y., Ly, B.T., Ishikawa, S., Kawano, Y., Itoh, S., 2012. Determination of an acceptable assimilable organic carbon (AOC) level for biological stability in water distribution systems with minimized chlorine residual. Environ. Monit. Assess, 185 (2), $1427-1436$

Okuda, T., Nishijima, W., Okada, M., 2006. Assimilable organic carbon (AOC) originating from picophytoplankton in drinking water. Water Supply 6 (2), 169-176.

Page, D., Dillon, P., 2007. Measurement of the biodegradable fraction of dissolved organic matter relevant to water reclamation via aquifers. Water for a Healthy Country National Research Flagship Report, CSIRO.

Park, N., Kwon, B., Sun, M., Ahn, H., Kim, C., Kwoak, C., Lee, D., Chae, S., Hyung, H. Cho, J., 2005. Application of various membranes to remove NOM typically occurring in Korea with respect to DBP AOC and transport parameters. Desalination 178 (1), 161-169.

Park, S.K., Choi, J.H., Hu, J.Y., 2012. Assessing bacterial growth potential in a model distribution system receiving nanofiltration membrane treated water. Desalination 296, 7-15.

Polanska, M., Huysman, K., van Keer, C., 2005. Investigation of assimilable organic carbon (AOC) in Flemish drinking water. Water Res. 39 (11), 2259-2266.

Prest, E.I., El-Chakhtoura, J., Hammes, F., Saikaly, P.E., van Loosdrecht, M.C.M., Vrouwenvelder, J.S., 2014. Combining flow cytometry and 16S rRNA gene pyrosequencing: a promising approach for drinking water monitoring and characterization. Water Res. 63, 179-189.

Prest, E.I., Hammes, F., van Loosdrecht, M.C.M., Vrouwenvelder, J.S., 2016. Biological stability of drinking water: controlling factors, methods, and challenges. Front. Microbiol. 7, 1-24.

Quek, S.B., Cheng, L., Cord-Ruwisch, R., 2014. Bio-electrochemical sensor for fast analysis of assimilable organic carbon in seawater. J. Biosens. Bioelectron. 5 (2), 1-4.

Quek, S.B., Cheng, L., Cord-Ruwisch, R., 2015. Microbial fuel cell biosensor for rapid assessment of assimilable organic carbon under marine conditions. Water Res. 77, 6471 .

Ramseier, M.K., Peter, A., Traber, J., von Gunten, U., 2011. Formation of assimilable organic carbon during oxidation of natural waters with ozone, chlorine dioxide, chlorine, permanganate, and ferrate. Water Res. 45 (5), 2002-2010.

Ross, P.S., Hammes, F., Dignum, M., Magic-Knezev, A., Hambsch, B., Rietveld, L.C., 2013. A comparative study of three different assimilable organic carbon (AOC) methods: results of a round-robin test. Water Sci. Technol. 13 (4), 1024-1033.

Ryu, H., Alum, A., Abbaszadegan, M., 2005. Microbial characterization and population changes in nonpotable reclaimed water distribution systems. Environ. Sci. Technol. 39 (22), 8600-8605.

Sathasivan, A., Ohgaki, S., 1999. Application of new bacterial regrowth potential method for water distribution system-a clear evidence of phosphorus limitation. Water Res. 33, $137-144$.

Shan, J.H., Hu, J.Y., Ong, S.L., 2005. Reclaiming biologically stable water from treated secondary effluent using a dual-membrane system. Environ. Eng. Sci. 22 (4), 525534.

Shaw, J.P., Malley, J.P., Willoughby, S.A., 2000. Effect of UV irradiation on organic matter. J. Am. Water Works Assoc. 92 (4), 157-167.

Silva, G.H.R., Daniel, L.A., Bruning, H., Rulkens, W.H., 2010. Anaerobic effluent disinfection using ozone: byproducts formation. Bioresour. Technol. 101, 6981-6986.

Singh, S., Fan, M., Brown, R.C., 2008. Ozone treatment of process water from a dry-mill ethanol plant. Bioresour. Technol. 99, 1801-1805.

Srinivasan, S., Harrington, G.W., 2007. Biostability analysis for drinking water distribution systems. Water Res. 41 (10), 2127-2138.

Suarez, S., Lema, J.M., Omil, F., 2009. Pre-treatment of hospital wastewater by coagulation-flocculation and flotation. Bioresour. Technol. 100, 2138-2146.

Thayanukul, P., Kurisu, F., Kasuga, I., Furumai, H., 2013. Evaluation of microbial regrowth potential by assimilable organic carbon in various reclaimed water and distribution systems. Water Res. 47, 225-232

Thayanukul, P., Kurisu, F., Kasuga, I., Kanaya, K., Furumai, H., 2016. Characterisation of biodegradable organic matter in reclaimed water using a bacterial growth fingerprint assay. Water Sci. Technol. Water Supply 16, 1225-1265.

Thomure, T.M., Rock, C., Choi, C., Williams, D.S., Pepper, I., Mclain, J., Lansey, K., Rahman, R., 2014. Approaches to maintaining consistently high quality recycled water in storage and distribution systems. WateReuse Research Foundation.

Tian, J.Y., Liang, H., Li, X., You, S.J., Tian, S., Li, G.B., 2008. Membrane coagulation bioreactor (MCBR) for drinking water treatment. Water Res. 42 (14), 3910-3920.

Tran, N.H., Ngo, H.H., Urase, T., Gin, K.Y., 2015. A critical review on characterization strategies of organic matter for wastewater and water treatment processes. Bioresour. Technol. 193, 523-533.

Tripathi, S., Pathak, V., Tripathi, D.M., Tripathi, B.D., 2011. Application of ozone based treatments of secondary effluents. Bioresour. Technol. 102, 2481-2486.

U.S. EPA, 2012. Guidelines for Water Reuse, EPA/600/R-12/618, U.S. EPA and U.S. Agency for International Development.

van der Kooij, D., 1999. Potential for biofilm development in drinking water distribution systems. J. Appl. Microbiol. Symp. Supple. 85, 39-44.

van der Kooij, D., Martijn, B., Schaap, P.G., Hoogenboezem, W., Veenendaal, H.R., van der Wielen, P.W.J.J., 2015. Improved biostability assessment of drinking water with suite of test methods at a water supply treating eutrophic lake water. Water Res. 87, 347-355.

van der Wielen, P.W.J.J., van der Kooij, D., 2010. Effect of water composition, distance and season on the adenosine triphosphate concentration in unchlorinated drinking water in the Netherlands. Water Res. 44, 4860-4867.

Verstraete, W., van de Caveye, P., Diamantis, V., 2009. Maximum use of resources present in domestic "used water". Bioresour. Technol. 100, 5537-5545.

Verstraete, W., Clauwaert, P., Vlaeminck, S.E., 2016. Used water and nutrients: recovery perspectives in a 'panta rhei' context. Bioresour. Technol. 215, 199-208.

Volk, C., Bell, K., Ibrahim, E., Verges, D., Amy, G., Lechevallier, M., 2000. Impact of enhanced and optimized coagulation on removal of organic matter and its biodegradable fraction in drinking water. Water Res. 34 (12), 3247-3257.

Wang, S.T., Ma, J., Liu, B.C., Jiang, Y.F., Zhang, H.Y., 2008. Degradation characteristics of secondary effluent of domestic wastewater by combined process of ozonation and biofiltration. J. Hazard. Mater. 109-114.

Wang, Q., Tao, T., Xin, K., 2014a. The relationship between water biostability and initial bacterial growth variations to different organic carbon concentrations. Proc. Eng. 89, $160-167$.

Wang, Q.H., Tao, T., Xin, K.L., Li, S.P., Zhang, W.F., 2014b. A review research of assimilable organic carbon bioassay. Desalin. Water Treat. 52 (13-15), 2734-2740.

Wang, J., Chu, H., Dong, B., 2015. Multiple views of biological stability and optimized coagulation in the control of biostability in traditional water treatment processes: a pilot test. Desalin. Water Treat. 57 (40), 18619-18629.

Weinrich, L.A., Giraldo, E., Lechevallier, M.W., 2009. Development and application of a bioluminescence-based test for assimilable organic carbon in reclaimed waters. Appl. Environ. Microbiol. 75 (23), 7385-7390.

Weinrich, L.A., Jjemba, P.K., Giraldo, E., LeChevallier, M.W., 2010. Implications of organic carbon in the deterioration of water quality in reclaimed water distribution systems. Water Res. 44 (18), 5367-5375.

Weishaar, J.L., Aiken, G.R., Bergamschi, B.A., Fram, M.S., Fujii, R., Mopper, K., 2003. Evaluation of specific ultraviolet absorbance as an indicator of the chemical composition and reactivity of dissolved organic carbon. Environ. Sci. Technol. 37 (20), 47024708.

Werner, P., Hambsch, B., 1986. Investigations on the growth of bacteria in drinking water. Water Supply 4 (3), 227-232

Wert, E.C., Rosario-Ortiz, F.L., Drury, D.D., Snyder, S.A., 2007. Formation of oxidation byproducts from ozonation of wastewater. Water Res. 41 (7), 1481-1490.

Wert, E.C., Neemann, J.J.D., Rexing, J., Zegers, R.E., 2008. Biofiltration for removal of $\mathrm{BOM}$ and residual ammonia following control of bromate formation. Water Res. 42 $(1-2), \quad 372-378$

Yang, C., Chen, H., Zeng, G., Yu, G., Luo, S., 2010. Biomass accumulation and control strategies in gas biofiltration. Biotechnol. Adv. 28, 531-540.

Yang, B.M., Liu, J.K., Chien, C.C., Surampalli, R.Y., Kao, C.M., 2011. Variations in AOC and microbial diversity in an advanced water treatment plant. J. Hydrol. 409 (1-2), 225-235.

Yu, T., Li, G., Lin, W., Hu, H., Lu, Y., 2017. Coagulation increased the growth potential of various species bacteria of the effluent of a MBR for the treatment of domestic wastewater. Environ. Sci. Pollut. Res. 24 (6), 5126-5133.

Yuan, H., He, Z., 2015. Integrating membrane filtration into bioelectrochemical systems as next generation energy-efficient wastewater treatment technologies for water reclamation: a review. Bioresour. Technol. 195, 202-209.

Zhang, J. Li, W.Y., Wang, F, Qian, L., Xu, C., Liu, Y, Oi, W., 2016. Exploring the biological stability situation of a full scale water distribution system in south China by three biological stability evaluation methods. Chemosphere 161,43-52.

Zhao, X., Hu, H.Y., Liu, S.M., Jiang, F., Shi, X.L., Li, M.T., Xu, X.Q., 2013. Improvement of the assimilable organic carbon (AOC) analytical method for reclaimed water. Front. Environ. Sci. Technol. 7 (4), 483-491.

Zhao, X., Huang, H., Hu, H.Y., Su, C., Zhao, J., Liu, S.M., 2014a. Increase of microbial growth potential in municipal secondary effluent by coagulation. Chemosphere 109, $14-19$.

Zhao, X., Hu, H.Y, Yu, T., Su, C., Jiang, H., Liu, S, 2014b. Effect of different molecular weight organic components on the increase of microbial growth potential of secondary effluent by ozonation. J. Environ. Sci. 26 (11), 2190-2197.

Zuthi, M.F.R., Guo, W., Ngo, H.H., Nghiem, D.L., Hai, F.I., Xia, S., Li, J., Li, J., Liu, Y., 2017. New and practical mathematical model of membrane fouling in an aerobic submerged membrane bioreactor. Bioresour. Technol. 238, 86-94. 